\title{
Hans Selye (1907-1982): Founder of the stress theory
}

\author{
Siang Yong $\underline{\operatorname{Tan}}^{1}$, MD, JD, $A{\underline{Y i p^{2}}}^{2}$ MS
}

$\mathrm{T}$ he relationship between stress and disease is now well established, but was not always recognised. The word 'stress' is used in physics to refer to the interaction between a force and the resistance to counter that force, and it was Hans Selye who first incorporated this term into the medical lexicon to describe the "nonspecific response of the body to any demand". Selye, who is known as the 'father of stress research', disavowed the study of specific disease signs and symptoms, unlike others before him, and instead focused on universal patient reactions to illness. His concept of stress impacted scientific and lay communities alike, in fields as diverse as endocrinology, complementary medicine, animal breeding and social psychology.

TRADITION OF EXCELLENCE Selye was born in Vienna on 26 January, 1907. His father, Hugo Selye, was a surgeon colonel in the Austro-Hungarian Imperial Army who later started his own surgical clinic. His mother, who administrated the clinic, had a strong influence on the boy with her constant quest for excellence and intellectual sophistication. Selye had a warm relationship with his father and it seemed inevitable that he would one day work in his father's surgical clinic. Carrying on the surgical work would mean continuing the medical tradition into the fifth generation of the family.

Selye received his education from a Benedictine monastery and private tutoring. By the age of four, he spoke four languages and would go on to learn several more. However, Selye was most proud of his Hungarian heritage, as his father was Hungarian and his teachers had impressed upon him a strong sense of nationalism. As a young child, he was confident

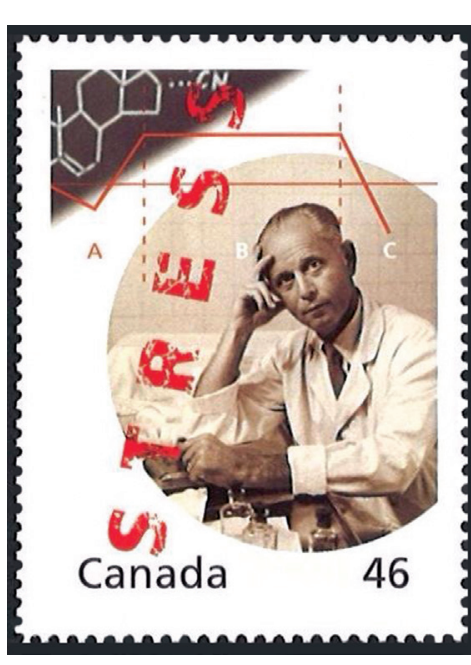

Canada. There, he completed his fellowship under Prof James Bertram Collip, the discoverer of the parathyroid hormone, and at the age of 27, became Assistant Professor of Biochemistry at McGill University.

Selye was first exposed to the idea of 'biological stress' during his second year at the University of Prague medical school. He had observed during ward rounds that patients often had numerous complaints in common, even though they were each suffering from different and distinct diseases. Until that point, students had been taught that signs and symptoms were related and specific to a particular illness, a principle passed down by the famous German pathologist Rudolf Virchow in the late 19th century. Recalling an example, Selye recounted how one of his teachers would make the correct diagnosis in each of five different patients, solely on the basis of their presenting history and physical findings. What was ignored, however, were the generic complaints that all those patients had in common, such as looking tired, having no appetite, losing weight, preferring to lie down rather than stand, and not being in the mood to go to work. He called it the "syndrome of just being sick". However, this obvious yet powerful observation would lie dormant for about ten years before Selye would launch his investigation into this ubiquitous phenomenon.

SELYE'S SYNDROME Selye was the first scientist to identify 'stress' as underpinning the nonspecific signs and symptoms of illness. The stress concept reentered Selye's life during his fellowship at McGill when Prof Collip placed him to the point of being boastful, always wanting to be first in everything that he did. These were personality traits that he carried into adulthood and which helped to sustain him in his pioneering work.

PATH TO RESEARCH Rather than taking over the family's surgical clinic, Selye chose a career in research instead. At 17, he attended the medical school of Charles University in Prague, Czech Republic. After receiving his Doctor of Medicine degree, he pursued a Doctor of Philosophy in organic chemistry, which earned him a Rockefeller Research Fellowship at Johns Hopkins University. However, he found university life at Hopkins unbearable and became homesick. He was on his way home to Prague when, following the advice of some Canadian students at Hopkins, he asked to transfer to McGill University in Montreal, in charge of identifying various female sex hormones that were yet undiscovered. For this project, he collected cow ovaries for processing and examination, and injected various extracts into female rats and measured their responses. His autopsies yielded a triad of surprising findings: enlargement of the adrenal glands, atrophy of the lymphatic system including the thymus, and peptic ulcers of the stomach and duodenum. It was not due to a hypothetical new hormone, as every injected noxious agent produced the same findings. He continued his experiments by placing the rats in various stressful situations, such as on the cold roof of the medical building, or the familiar revolving treadmill that required continuous running for the animals to stay upright. The findings in each experiment were the same: adrenal hyperactivity, lymphatic atrophy and peptic ulcers.

${ }^{1}$ Emeritus Professor of Medicine, ${ }^{2}$ Research carried out during senior medical student elective, John A Burns School of Medicine, University of Hawaii, Honolulu, USA Correspondence: Prof Tan Siang Yong, 2226 Liliha Street, Suite B-104, Honolulu, HI 96817, USA. siang@hawaii.edu 
Selye recognised that his discovery was an expression of Claude Bernard's milieu intérieur and homeostasis at work, and cleverly linked the hypothalamic-pituitary-adrenal axis to the way the body coped with stress.

Selye's proposal stipulated that stress was present in an individual throughout the entire period of exposure to a nonspecific demand. He distinguished acute stress from the total response to chronically applied stressors, terming the latter condition 'general adaptation syndrome', which is also known in the literature as Selye's Syndrome. The syndrome divides the total response from stress into three phases: the alarm reaction, the stage of resistance and the stage of exhaustion. When individuals are exposed to a stressor, they are at first taken off guard, then attempt to maintain homeostasis by resisting the change, and eventually fall victim to exhaustion in countering the stressor. Stress is a choreographed state of events, not a mere psychological term, and is encountered by all individuals during a period of illness. It differs fundamentally from the fight-or-flight or acute stress response that occurs when facing a perceived threat, as first described by physiologist Walter Cannon in 1915. The acute release of neurotransmitters from the sympathetic and central nervous systems, as well as hormones from the adrenal cortex and medulla, pituitary and other endocrine glands, mediate the response in acute stress.

LIFE AND WORK Work was never work for Selye; in this regard, he has been compared to Thomas Edison, who saw work not as labour but as leisure. Selye actually transformed his home, a brick house built across the McGill University campus, into the International Institute of Stress, where he planned some of his experiments. Notwithstanding his prodigious contributions, Selye's personal life was one of tumult. He was married three times and had one daughter from his first marriage and four children from his second. He purportedly stayed in his second marriage for 28 years because he wanted to provide a good home for his children until they were independent. His third and final marriage was to Louise, his laboratory assistant of 19 years and someone whom he felt had always understood his goals. In his memoirs, Selye compared himself to a racehorse with Louise riding on his back, racing together toward the finishing line.

Selye's relentless work ethic was evident in his publications, which numbered more than 1,600 scientific articles and about 40 books. An innovative and creative scientist with a rich and invigorating personality, he considered himself a practitioner of experimental, not clinical, medicine. He even delved into the association between stress and cancer, using his own personal experience after a histiocytic reticulosarcoma formed under his skin, for which he had to undergo surgery and radioactive cobalt therapy. He was a nominee for the Nobel Prize in 1949, won many accolades, and published his best-known book, The Stress of Life, in 1956. A professor and director of the Institute of Experimental Medicine and Surgery at the University of Montreal, he at one point directed 40 laboratory assistants and worked with 15,000 laboratory animals. In 1975, he founded the International Institute of Stress, and created the Hans Selye Foundation and the Canadian Institute of Stress.

Selye died on 16 October 1982, in Montreal at the age of 75. Sadly, a scandal emerged after his death: he was said to have received extensive funding for his research from the tobacco industry, for which he had worked as a consultant over several decades, as well as participating in its pro-smoking campaigns.

\section{BIBLIOGRAPHY}

- Csermely P. Stress of Life: From Molecules to Man. New York: New York Academy of Sciences, 1998.

- Kovacs K. Hans Selye: The Original and Creative Scientist. Ann N Y Acad Sci 1998; 851:13-5.

- Malmo RB. Hans Hugo Selye (1907-1982). American Psychologist 1986; 41:92-3.

- Neufeld RW. Psychological Stress and Psychopathology. New York: McGrawHill Book Company, 1982.

- Perdrizet GA. Hans Selye and Beyond: Responses to Stress. Cell Stress Chaperones $1997 ; 2: 214-9$.

- Selye H. The Stress of Life. New York: McGraw-Hill Book Company, 1956.

- Selye H. Stress of My Life: A Scientist's Memoirs. New York: Van Nostrand Reinhold Company, 1979.

- Szabo S. Hans Selye and the development of the stress concept. Special reference to gastroduodenal ulcerogenesis. Ann N Y Acad Sci 1998; 851:19-27.

- Taché J. Cancer, Stress, and Death. New York: Plenum Medical Book Company, 1979.

- Viner R. Putting Stress in Life: Hans Selye and the Making of Stress Theory. Social Studies of Science 1999; 29:391-410. 